\begin{tabular}{|r||l|r|}
\hline Al Fitrah & Pengaruh Edukasi Gizi Seimbang \\
Journal Of Early Childhood Islamic Education & dengan Permainan Kartu Bergambar \\
ISSN : 2599-2287 E-ISSN : 2622-335X & Afifah Nufaisah, Emy \\
Vol.3 No.1Juli 2019 & Yuliantini, Darwis \\
\hline
\end{tabular}

\title{
PENGARUH EDUKASI GIZI SEIMBANG DENGAN PERMAINAN KARTU BERGAMBAR DAN PUZZLE TERHADAP PENGETAHUAN ANAK MADRASAH IBTIDAIYAH NEGERI 2 KOTA BENGKULU TAHUN 2019
}

\begin{tabular}{|c|c|}
\hline $\begin{array}{l}\text { Abstrak } \\
\text { Gizi Seimbang adalah susunan pangan sehari-hari } \\
\text { yang mengandung zat gizi dalam jenis dan jumlah } \\
\text { yang sesuai dengan kebutuhan tubuh. Menurut } \\
\text { Achadi, dkk (2010) anak-anak belum memahami } \\
\text { konsep gizi seimbang, akan tetapi anak-anak masih } \\
\text { terpaku pada empat sehat lima sempurna. Tujuan } \\
\text { Penelitian untuk diketahui pengaruh edukasi gizi } \\
\text { seimbang dengan permainan kartu bergambar dan } \\
\text { permainan puzzle terhadap pengetahuan anak di } \\
\text { Madrasah Ibtidaiyah Negeri } 2 \text { kota Bengkulu Tahun } \\
\text { 2019. Penelitian ini menggunakan desain Quasi } \\
\text { Eksperiment dengan rancangan yaitu two group pre- } \\
\text { test post-test. Sampel dalam penelitian ini sebanyak } 48 \\
\text { anak. Pengambilan sampel dalam penelitian ini } \\
\text { menggunakan tehknik purposive sampling yang } \\
\text { memenuhi kriteria inklusi. Sample dalam penelitian } \\
\text { ini berjumlah 48 orang yang dibagi menjadi dua } \\
\text { kelompok dengan pemberian edukasi menggunakan } \\
\text { permainan kartu bergambar dan puzzle. Berdasarkan } \\
\text { hasil uji paired samples t test menunjukkan ada } \\
\text { perbedaan pengaruh yang bermakna antara } \\
\text { pengetahuan sanak sebelum dan sesudah diberikan } \\
\text { permainan kartu bergambar dan puzzle (P Value = } \\
\text {.000). Berdasarkan hasil uji independent samples t test } \\
\text { terdapat perbedaan pengaruh yang bermakna antara } \\
\text { perubahan nilai pengetahuan siswa yang diberikan } \\
\text { permainan kartu bergambar dan permainan puzzle (P } \\
\text { Value = .002). Pada kedua permainan ini didapatkan } \\
\text { permainan kartu bergambar lebih efektif dibandingkan } \\
\text { permainan puzzle dengan selisih nilai rata-rata 34,84. } \\
\text { Hal ini dikarenakan pada permainan kartu bergambar } \\
\text { kognitif anak bertambah dengan cara membaca, } \\
\text { mendengarkan dan melihat gambar yang ada dikartu } \\
\text { bergambar. Sedangkan pada permainan puzzle anak } \\
\text { hanya menyusun potongan-potongan gambar dengan } \\
\text { secepat mungkin. } \\
\text { Kata Kunci : Gizi Seimbang, Pengetahuan, Edukasi, } \\
\text { Kartu bergambar, Puzzle }\end{array}$ & $\begin{array}{r}\text { Afifah Nufaisah }{ }^{1} \text {, } \\
\text { Emy Yuliantini }^{2} \\
\text { Darwis }^{3} \\
\text { 1afifahnufaisah.an@gmail.com } \\
{ }_{2} \text { emy.yuliantini@gmail.com } \\
3 \text { darwis.da@gmail.com } \\
1,2,3 \text { Jurusan Gizi Politeknik } \\
\text { Kementerian Kesehatan } \\
\text { Bengkulu }\end{array}$ \\
\hline
\end{tabular}

\section{PENDAHULUAN}

Gizi Seimbang adalah susunan pangan sehari-hari yang mengandung zat gizi dalam jenis dan jumlah yang sesuai dengan kebutuhan tubuh, dengan memperhatikan prinsip keanekaragaman pangan, aktivitas 


\begin{tabular}{|l|l|r|}
\hline & Al Fitrah & Pengaruh Edukasi Gizi Seimbang \\
Journal Of Early Childhood Islamic Education & dan Puzzle... \\
ISSN : 2599-2287 E-ISSN : 2622-335X & Affifah Nufaisah, Emy \\
& Vol.3 No.1Juli 2019 & Yuliantini, Darwis \\
\hline
\end{tabular}

fisik, perilaku hidup bersih dan mempertahankan berat badan normal untuk mencegah masalah gizi (Kemenkes, 2014).

Gizi seimbang diperlukan anak sekolah untuk pertumbuhan, fisik dan mental anak. Menurut Susilowati dan Kuspriyanto (2016) menyatakan bahwa kelompok anak usia sekolah (7-12 tahun) merupakan kelompok rentan gizi dan yang paling mudah menderita kelainan gizi serta yang berhubungan dengan proses pertumbuhan yang relatif pesat, sehingga memerlukan asupan gizi yang relative besar.

Masih banyak anak sekolah dasar yang belum mengetahui tentang gizi seimbang. Menurut Achadi, dkk (2010) anak-anak belum memahami konsep gizi seimbang, akan tetapi anak-anak masih terpaku pada empat sehat lima sempurna. 90\% anak menjawab empat sehat lima sempurna sama dengan gizi seimbang. Anak-anak juga berpendapat bahwa makan nasi lebih banyak dari pada lauk dan sayuran. Selain itu tiga perempat dari anakanak menyatakan bahwa minum susu saja sudah cukup, tidak memerlukan makanan lainnya.

Supriasa (2015) menyatakan bahwa pendidikan gizi adalah pendekatan penyebarluasan informasi gizi berdasarkan kaidah-kaidah ilmu gizi. Umumnya, informasi yang disampaikan sesuai dengan masalah-masalah yang di hadapi masyarakat, seperti bagaimana memilih makanan bergizi, gizi seimbang, kebiasaan makan, masalah pantangan makan, mempertahankan berat badan ideal.

Salah satu faktor yang mendukung pengetahuan anak tentang gizi seimbang adalah edukasi atau pendidikan. Menurut Wahyuningsih, dkk (2015) salah satu upaya yang dapat dilakukan untuk menghindari anak sekolah dasar dari bahaya makanan jajanan yang tidak sehat adalah dengan memberikan edukasi gizi. Dengan memberikan pendidikan atau edukasi tentang makanan sehat selama masa anak- anak tidak hanya dapat mencegah beberapa penyebab penyakit utama dan kematian, tetapi juga dapat menurunkan biaya kesehatan dan dapat meningkatkan kualitas hidup manusia.

Wahyuningsih, (2015) edukasi gizi merupakan bagian terpenting dari kurikulum sekolah. Dengan adanya pendidikan gizi di lingkungan sekolah dapat memberikan pengaruh positif terhadap pengetahuan, sikap, dan tindakan anak-anak sehingga anak-anak bisa menjadi salah satu faktor penentu keberhasilan program pendidikan gizi adalah metode dan media yang digunakan.

Media pembelajaran memiliki peran penting dalam menunjang proses pembelajaran. Menurut Hamalik penggunaan media pembelajaran dalam proses belajar dapat membangkitkan keinginan dan minat yang baru. Selain itu dengan menggunakan media pembelajaran juga dapat membangkitkan motivasi dan rangsangan kegiatan belajar bahkan membawa pengaruh-pengaruh psikoligis terhadap siswa (Arsyad, 2013).

Salah satu media yang dapat digunakan adalah permainan kartu bergambar dan puzzle. Kartu bergambar atau lebih dikenal dengan nama flash card adalah kartu kecil yang berisi gambar, teks, atau tanda simbol yang mengingatkan atau menuntun siswa kepada sesuatu yang berhubungan dengan gambar itu (Arsyad, 2013). Sedangkan puzzle adalah permainan menyusun dan mencocokan bentuk dan tempatnya sesuai dengan gambar yang sebenarnya (Yulianty, 2008). Hal ini sejalan dengan hasil penelitian yang dilakukan oleh Wahyuningsih, dkk (2015) bahwa ada perbedaan pengetahuan yang signifikan setelah diberikan pendidikan gizi dengan media nutrition card.

Berdasarkan hasil penelitian yang dilakukan oleh Virmando (2018) menunjukkan ada perbedaan sikap dan perilaku gizi pada pendidikan gizi yaitu sebesar $(97,1 \%)$ setelah intervensi, $(95,6 \%)$ 


\begin{tabular}{|c|c|c|}
\hline & $\begin{array}{l}\text { A1 Fitrah } \\
\text { Journal of Early Childhood Islamic Education } \\
\text { ISSN : 2599-2287 E-ISSN : 2622-335X } \\
\text { Vol.3 No.1Juli } 2019\end{array}$ & $\begin{array}{r}\text { Pengaruh Edukasi Gizi Seimbang } \\
\text { dengan Permainan Kartu Bergambar } \\
\text { dan Puzzle... } \\
\text { Afifah Nufaisah, Emy } \\
\text { Yuliantini, Darwis }\end{array}$ \\
\hline
\end{tabular}

sebelum intervensi dan perubahan perilaku gizi baik yang meningkat sesudah intervensi (45,6\%).

Berdasarkan hasil penelitian yang dilakukan oleh Hikmawati, dkk (2016) menunjukkan bahwa ada pengaruh penyuluhan dengan media promosi puzzle gizi yang diberikan kepada siswa dalam meningkatkan pengetahuan, sikap dan tindakan siswa tentang gizi seimbang. Selain itu menurut Demitri (2015) menunjukkan bahwa ada pengaruh pendidikan gizi melalui game puzzle yang dapat meningkatkan pengetahuan anak sekolah tentang pola makan seimbang. Sebelum dilakukan pendidikan gizi pada anak, kategori pengetahuan kurang baik sebesar 26,7\%, setelah dilakukan pendidikan gizi tidak ada lagi anak dalam kategori pengetahuan kurang baik.

Menurut data pengetahuan anak tentang gizi seimbang yang didapat melalui survey awal di Madrasah Ibtidaiyah Negeri 2 kota Bengkulu tahun 2018 menunjukan bahwa pengetahuan anak termasuk kategori kurang yaitu sebesar $48 \%$.

Tujuan umum penelitian ialah diketahui pengaruh edukasi gizi seimbang dengan permainan kartu bergambar dan permainan puzzle terhadap pengetahuan anak di Madrasah Ibtidaiyah Negeri 2 kota Bengkulu.

Tujuan khusus adalah diketahui pengetahuan gizi seimbang anak sebelum diberi edukasi gizi seimbang dengan permianan kartu bergambar di Madrasah Ibtidaiyah Negeri 2 Kota Bengkulu, diketahui pengetahuan gizi seimbang anak sebelum diberi edukasi gizi seimbang dengan permainan puzzle di Madrasah Ibtidaiyah Negeri 2 Kota Bengkulu, diketahui pengetahuan gizi seimbang anak sesudah diberi edukasi gizi seimbang dengan permainan kartu bergambar di Madrasah Ibtidaiyah Negeri 2 Kota Bengkulu, diketahui pengetahuan gizi seimbang anak sesudah diberi edukasi gizi seimbang dengan permainan puzzle di
Madrasah Ibtidaiyah Negeri 2 Kota Bengkulu, diketahui yang paling berpengaruh antara permainan kartu bergambar dan puzzle dalam meningkatkan pengetahuan gizi seimbang anak di Madrasah Ibtidaiyah Negeri 2 kota Bengkulu.

\section{METODE}

Penelitian ini menggunakan desain Quasi Eksperiment dengan rancangan yaitu two group pre-test post-test.

Penelitian dilakukan di Madrasah Ibtidaiyah Negeri 2 Kota Bengkulu. Adapun waktu penelitian ini adalah pada 06 Mei - 18 Mei 2019.

Populasi dalam penelitian ini adalah semua siswa kelas IV madrasah ibtidaiyah negeri 2 kota Bengkulu yang berjumlah 176 siswa.

Pengambilan sampel menggunakan teknik Sampling Purposive dengan kriteria inklusi dan ekslusi.

Sampel yang dibutuhkan secara keseluruhan adalah 2 kelompok x 24 orang = 48 anak. Sampel yang digunakan yaitu 2 kelas yang dipilih secara acak. Kelas pertama untuk permainan kartu bergambar dan kelas kedua untuk permainan puzzle.

Alat pengumpulan data menggunakan instrument penelitian yaitu berupa kuesioner. Kuesioner ini terdiri dari 14 pertanyaan dalam bentuk multiple choice untuk mengukur pengetahuan anak.

Analisis univariat dilakukan untuk mendeskripsikan variabel bebas yaitu media kartu bergambar dan media puzzle, variabel terikat yaitu pengetahuan 10 pesan gizi seimbang. Analisis univariat ini disajikan dalam bentuk tabel distribusi frekuensi. Analisis bivariat merupakan analisa untuk mengetahui interaksi dua variabel atau digunakan untuk menilai hubungan antara variabel bebas dan variabel terikat. Data yang diperoleh dianalisis menggunakan uji T-Test Paired dan uji T-Test Independent jika data terdistribusi normal, untuk 


\begin{tabular}{|l|l|r||}
\hline & Al Fitrah & Pengaruh Edukasi Gizi Seimbang \\
Journal Of Early Childhood Islamic Education & dengan Permainan Kartu Bergambar \\
ISSN : 2599-2287 E-ISSN : 2622-335X & Afifah Nufaisah, Emy \\
\hline & Yuliantini, Darwis \\
\hline
\end{tabular}

distribusi data tidak normal digunakan uji Mann-Whitney atau wilcoxon.

\section{HASIL DAN PEMBAHASAN Hasil}

\section{Analisis Univariat}

\section{Tabel. 4.1 Gambaran Pengetahuan Gizi Seimbang}

\begin{tabular}{cccccc}
\hline $\begin{array}{c}\text { Variabel } \\
\text { Pengetahuan }\end{array}$ & $\begin{array}{c}\text { Penguku } \\
\text { ran }\end{array}$ & $\begin{array}{c}\text { Min } \\
- \\
\text { Max }\end{array}$ & Mean & SD & $\begin{array}{c}\text { P } \\
\text { Value }\end{array}$ \\
\hline $\begin{array}{c}\text { Permainan } \\
\text { Kartu }\end{array}$ & Sebelum & $\begin{array}{c}36- \\
57\end{array}$ & 45.62 & 7.67 & \\
$\begin{array}{c}\text { Bergambar } \\
\text { Sesudah }\end{array}$ & $\begin{array}{c}71- \\
93\end{array}$ & 80.46 & 7.87 & \\
\hline & Selisih & & 34.84 & & \\
\hline
\end{tabular}

Pada table 4.1 didapatkan nilai ratarata pengetahuan dari 24 sampel sebelum penggunaan permainan kartu bergambar untuk edukasi gizi seimbang adalah 45,62 dan setelah penggunaan permainan kartu bergambar untuk edukasi gizi seimbang adalah 80,46. Adapun nilai rata-rata pengetahuan dari 24 sampel sebelum penggunaan permainan puzzle untuk edukasi gizi seimbang adalah 43,88 dan setelah penggunaan permainan puzzle untuk edukasi gizi seimbang adalah 72,96. Nilai pengetahuan meningkat setelah diberikan edukasi gizi seimbang menggunakan permainan kartu bergambar dan puzzle.

Berdasarkan hasil pre-test didapatkan hasil bahwa tingkat pengetahuan responden terbanyak sebelum diberikan permainan kartu bergambar dan puzzle adalah kategori sedang sebanyak 3 orang (12,5\%), paling banyak dengan kategori kurang sebanyak 21 orang (87,5\%). Hal ini menunjukkan bahwa tingkat pengetahuan siswa tentang gizi seimbang masih kurang.

Sedangkan hasil post-test pada kartu bergambar dengan kategori sedang sebanyak 7 orang (29,2\%), sedangkan dengan kategori baik sebanyak 17 orang
(70,8\%). Untuk hasil post-test pada permainana puzzle dengan kategori sedang sebanyak 12 orang (50\%) dan untuk kategori baik sebanyak 12 orang (50\%). Hal ini menunjukkan bahwa tingkat pengetahuan siswa setelah diberikan permainan kartu bergambar dan puzzle mengalami peningkatan jumlah dengan kategori sedang maunpun baik.

\section{Analisis Bivariat}

Tabel. 4.2 Hasil Uji Statistik Perbedaan Pengetahuan Sebelum dan Sesudah Diberikan Edukasi Gizi Seimbang Menggunakan Permainan Kartu Bergambar

\begin{tabular}{ccccccc}
\hline $\begin{array}{c}\text { Variabel } \\
\text { Pengetah } \\
\text { uan }\end{array}$ & $\begin{array}{c}\text { Pengu } \\
\text { kuran }\end{array}$ & N & Mean & SD & Min & Max \\
\hline $\begin{array}{c}\text { Permain } \\
\text { an } \\
\text { Kartu } \\
\text { Bergamb } \\
\text { ar }\end{array}$ & $\begin{array}{c}\text { Sebelu } \\
\text { m }\end{array}$ & 24 & 45.62 & 7.67 & 36 & 57 \\
$\begin{array}{c}\text { Permain } \\
\text { an } \\
\text { Puzzle }\end{array}$ & $\begin{array}{c}\text { Sebelu } \\
\text { m }\end{array}$ & 24 & 43.88 & 7.80 & 36 & 57 \\
\hline $\begin{array}{c}\text { Permain } \\
\text { an } \\
\text { Kartu } \\
\text { Bergamb } \\
\text { ar }\end{array}$ & $\begin{array}{c}\text { Sesuda } \\
\text { h }\end{array}$ & 24 & 80.46 & 7.87 & 71 & 93 \\
$\begin{array}{c}\text { Permain } \\
\text { an } \\
\text { Puzzle }\end{array}$ & $\begin{array}{c}\text { Sesuda } \\
\text { h }\end{array}$ & 24 & 72.96 & 7.91 & 64 & 86 \\
\hline
\end{tabular}

Pada Tabel 4.2 didapatkan nilai ratarata pengetahuan dari 24 sampel sebelum diberikan edukasi gizi seimbang menggunakan permainan kartu bergambar adalah 45,62 dengan standar deviasi 7,67 dan meningkat sesudah diberikan edukasi gizi seimbang menggunakan permainan kartu bergambar menjadi 80,46 dengan standar deviasi 7,87.

Berdasarkan hasil uji paired samples $t$ test pada pengetahuan didapatkan $P$ Value $=.000$ sehingga $P$ Value $<0,05$ dan berarti terdapat perbedaan pengaruh yang bermakna antara pengetahuan siswa sebelum dan sesudah diberikan edukasi gizi seimbang menggunakan media kartu bergambar. 


\begin{tabular}{|l|l|r|}
\hline Al Fitrah & Pengaruh Edukasi Gizi Seimbang \\
Journal Of Early Childhood Islamic Education & dengan Puzzle... \\
ISSN : 2599-2287 E-ISSN : 2622-335X & Afifmainan Kartu Bergan \\
Vol.3 No.1Juli 2019 & Afifah Nufaisah, Emy \\
\hline
\end{tabular}

Tabel. 4.3 Hasil Uji Statistik Perbedaan Pengetahuan Sebelum dan Sesudah Diberikan Edukasi Gizi Seimbang Menggunakan Permainan Puzzle

\begin{tabular}{|c|c|c|c|c|c|}
\hline $\begin{array}{c}\text { Varia } \\
\text { bel } \\
\text { Penge } \\
\text { tahua } \\
\text { n } \\
\end{array}$ & $\begin{array}{c}\text { Peng } \\
\text { ukur } \\
\text { an }\end{array}$ & $\begin{array}{c}\text { Min - } \\
\text { Max }\end{array}$ & Mean & SD & $\begin{array}{c}\mathbf{P} \\
\text { Value }\end{array}$ \\
\hline \multirow{3}{*}{$\begin{array}{c}\text { Perm } \\
\text { ainan } \\
\text { Puzzl } \\
\text { e }\end{array}$} & $\begin{array}{l}\text { Sebel } \\
\text { um }\end{array}$ & $36-57$ & 43.88 & 7.80 & \multirow{3}{*}{.000} \\
\hline & $\begin{array}{l}\text { Sesud } \\
\text { ah }\end{array}$ & $64-86$ & 72.96 & 7.91 & \\
\hline & $\begin{array}{c}\text { Selisi } \\
\mathrm{h}\end{array}$ & & 29.08 & & \\
\hline
\end{tabular}

Pada Tabel 4.3 didapatkan nilai rata-rata pengetahuan dari 24 sampel sebelum diberikan edukasi gizi seimbang menggunakan permainan puzzle adalah 43,88 dengan standar deviasi 7,80 dan meningkat sesudah diberikan edukasi gizi seimbang menggunakan permainan puzzle menjadi 72,96 dengan standar deviasi 7,91.

Berdasarkan hasil uji paired samples $t$ test pada pengetahuan didapatkan $P$ Value $=.000$ sehingga $P$ Value $<0,05$ dan berarti terdapat perbedaan pengaruh yang bermakna antara pengetahuan siswa sebelum dan sesudah diberikan edukasi gizi seimbang menggunakan permainan puzzle.

Tabel. 4.4 Perubahan Nilai Pengetahuan Siswa Sesudah Diberikan Edukasi Gizi Seimbang Menggunakan Permainan Kartu Bergambar dan Puzzle

\begin{tabular}{cccccc}
\hline $\begin{array}{c}\text { Variabel } \\
\text { Pengetahuan }\end{array}$ & $\mathbf{N}$ & Mean & $\begin{array}{c}\text { Min } \\
-\end{array}$ & SD & $\begin{array}{c}\text { P } \\
\text { Value }\end{array}$ \\
\hline $\begin{array}{c}\text { Permainan } \\
\text { Kartu }\end{array}$ & 24 & 80.46 & $\begin{array}{c}71- \\
93\end{array}$ & 7.87 & \\
Bergambar & & & & & \\
$\begin{array}{c}\text { Permainan } \\
\text { Puzzle }\end{array}$ & 24 & 72.96 & $\begin{array}{c}64- \\
86\end{array}$ & 7.91 & \\
\hline
\end{tabular}

Pada Tabel 4.4 didapatkan perubahan nilai pengetahuan siswa sesudah diberikan edukasi gizi seimbang menggunakan permainan kartu bergambar memiliki nilai rata-rata 80,46 dengan standar deviasi 7,87. Sedangkan perubahan nilai pengetahuan siswa sesudah diberikan edukasi gizi seimbang menggunakan permainan puzzle memiliki nilai rata-rata 72,96 dengan standar deviasi 7,91.

Berdasarkan hasil uji independent samples $t$ test pada perubahan nilai pengetahuan didapatkan $P$ Value $=.002$ sehingga $P$ Value $<0,05$ dan berarti terdapat perbedaan pengaruh yang bermakna antara perubahan nilai pengetahuan siswa yang diberikan edukasi gizi seimbang dengan menggunakan permainan kartu bergambar dan permainan puzzle.

\section{Pembahasan}

Perbedaan Pengetahuan Siswa yang Diberikan Edukasi Gizi Seimbang dengan Menggunakan Permainan Kartu Bergambar dan Media Puzzle di MIN 2 Kota Bengkulu Tahun 2019.

Hasil penelitian menunjukkan bahwa pengetahuan responden meningkat setelah diberikan edukasi dengan menggunakan permainan kartu bergambar dan permainan puzzle. Sesudah diberikan edukasi gizi seimbang menggunakan permainan kartu bergambar dan permainan puzzle, nilai rata-rata pengetahuan responden lebih tinggi dibandingkan dengan nilai pengetahuan responden sebelum diberikan edukasi gizi seimbang menggunakan media kartu bergambar dan media puzzle.

$$
\text { Edukasi gizi seimbang }
$$
menggunakan permainan kartu bergambar dan permainan puzzle diberikan sebanyak 1 kali setiap minggu selama 2 minggu. Adapun variabel pengetahuan diukur menggunakan kuesioner dan dilakukan sebanyak 2 kali, yakni 1 kali sebelum diberikannya edukasi gizi seimbang menggunakan permainan kartu bergambar dan permainan puzzle pada minggu pertama serta 1 kali setelah diberikannya edukasi 


\begin{tabular}{|c|c|c|}
\hline & $\begin{array}{l}\text { A1 Fitrah } \\
\text { Journal of Early Childhood Islamic Education } \\
\text { ISSN : 2599-2287 E-ISSN : 2622-335X } \\
\text { Vol.3 No.1Juli } 2019\end{array}$ & $\begin{array}{r}\text { Pengaruh Edukasi Gizi Seimbang } \\
\text { dengan Permainan Kartu Bergambar } \\
\text { dan Puzzle... } \\
\text { Afifah Nufaisah, Emy } \\
\text { Yuliantini, Darwis }\end{array}$ \\
\hline
\end{tabular}

gizi seimbang menggunakan permainan kartu bergambar dan permainan puzzle pada minggu kedua.

Proses edukasi gizi seimbang pada responden menggunakan permainan kartu bergambar dan permainan puzzle. Peneliti terlebih dahulu membagi responden menjadi dua kelompok yang diambil secara acak (menggunakan sistem undian pada kelas dan nama siswa yang dipilih). Tiap kelompok terdiri dari 24 orang yang dijadikan sampel, yakni kelompok 1 yang diberikan edukasi gizi seimbang menggunakan permainan kartu bergambar dan kelompok 2 yang diberikan edukasi gizi seimbang menggunakan permainan puzzle.

Pada edukasi gizi seimbang menggunakan media kartu bergambar disediakan kartu bergambar untuk dimainkan secara berkelompok dengan jumlah 4 orang. Sedangkan pada edukasi gizi seimbang menggunakan permainan puzzle disediakan 1 puzzle per kelompok yang terdiri dari 4 orang yang disusun secara bersama. Edukasi gizi seimbang menggunakan media kartu bergambar dan media puzzle dimainkan secara berulang sebanyak 2 kali tiap kelompok.

Hasil dari kuesioner pre-test pada kedua permainan yang diberikan kepada anak terkait gizi seimbang yaitu ditemukan beberapa responden banyak menjawab salah pada pertanyaan nomor 14, 3 dan 13 yaitu tentang anjuran porsi makan buah dalam sehari, yang manakah termasuk lauk pauk berprotein dan anjuran makan buah pisang dalam satu kali makan. Hal ini dikarenakan kurangnya pengetahuan responden mengenai gizi seimbang yang mana kemungkinan bisa menjadi banyak benar bila menggunakan media food model dimana dengan media ini anak diberikan secara langsung contoh bahan makanan tersebut. Hal ini sejalan dengan Sadiman, dkk (1989) yaitu tidak ada satu mediapun yang dapat sesuai dan cocok untuk segala macam kegiatan belajar.
Hasil dari kuesioner post-test dari kedua permainan yang diberikan kepada anak terkait gizi seimbang yaitu ditemukan beberapa responden banyak menjawab benar pada pertanyaan nomor 1, 6, dan 12 yaitu tentang anjuran minum untuk satu hari manfaat sarapan dan lama aktifitas fisik dalam satu hari.

Hasil uji statistic t-test paired pada pretest dan posttest didapatkan nilai $P$ value $0.000<0.05$ ini berarti ada perbedaan pengaruh terhadap pengetahuan anak sebelum dan sesudah diberi edukasi terkait gizi seimbang. Dari hasil yang dilakukan oleh peneliti didapatkan bahwa terjadi peningkatan pengetahuan anak sebelum dan sesudah diberikan edukasi menggunakan permainan kartu bergambar dan puzzle namun pada kedua media ini didapatkan media yang lebih tinggi pengaruhnya terhadap pengetahuan anak yaitu edukasi dengan permainan kartu bergambar yang dilihat dari hasil rata-rata selisih pengetahuan sebelum dan sesudah diberikan edukasi menggunakan permainan kartu bergambar yaitu rata-rata skor 34.84 sedangkan edukasi menggunakan permainan puzzle lebih rendah yaitu ratarata skor 29.08 .

Hasil uji statistic Independent T-test pada perubahan skor pengetahuan pretest dan postet anak yang diberi edukasi dengan menggunakan permainan kartu bergambar dan puzzle didapatkan nilai rata-rata pada edukasi permainan kartu bergambar yaitu 80.46 dengan standar deviasi 7.87 sedangkan pada edukasi permainan puzzle yaitu 72.96 dengan standar deviasi 7.91 dan pada nilai $P$ Value $0.002<0,05$. Hasil perubahan skor ini membuktikan bahwa terdapat perbedaan pengaruh yang bermakna dari kedua permainan ini.

Pada kedua permainan ini didapatkan permainan kartu bergambar lebih efektif dibandingkan permainan puzzle dengan selisih nilai rata-rata 34,84. Hal ini dikarenakan pada permainan kartu bergambar kognitif anak bertambah dengan 


\begin{tabular}{|c|c|c|}
\hline & $\begin{array}{l}\text { A1 Fitrah } \\
\text { Journal Of Early Childhood Islamic Education } \\
\text { ISSN : 2599-2287 E-ISSN : 2622-335X } \\
\text { Vol.3 No.1Juli } 2019\end{array}$ & $\begin{array}{r}\text { Pengaruh Edukasi Gizi Seimbang } \\
\text { dengan Permainan Kartu Bergambar } \\
\text { dan Puzzle... } \\
\text { Afifah Nufaisah, Emy } \\
\text { Yuliantini, Darwis }\end{array}$ \\
\hline
\end{tabular}

cara membaca, mendengarkan dan melihat gambar yang ada dikartu bergambar. Sedangkan pada permainan puzzle anak hanya menyusun potongan-potongan gambar dengan secepat mungkin.

Adapun kelebihan dari kartu bergambar ialah tedapat gambar yang sesuai dengan keterangan yang ada (gambar lebih spesifik), sedangkan kekurangganya ialah gambar pada kartu bergambar terbatas sehingga anak-anak harus melihat semua kartu bergambar untuk lebih jelasnya dan memerlukan waktu yang lama untuk anak melihat semua kartu bergambar.

Kelebihan dari puzzle ialah dalam satu puzzle sudah mencangkup semua gambar sehingga tidak memerlukan waktu yang lama untuk melihatnya, sedangkan kekurangannya ialah keterangan pada puzzle itu masih secara umum.

Penelitian ini sejalan dengan penelitian yang dilakukan oleh (Wahyuningsih, 2015) bahwa media nutrition card yang digunakan dalam penelitiannya untuk mengetahui tingkat pengetahuan responden menunjukkan terjadinya peningkatan pengetahuan yaitu rata-rata pengetahuan anak sebelum intervensi sebesar 7,59 dan sesudah intervensi sebesar 8,92 dengan selisih rata-rata sebelum dan sesudah intervensi yaitu 1,33. Sedangkan hasil pengukuran pengetahuan sebelum diberikan intervensi dengan media papan tulis sebesar 7,62 dan sesudah intervensi sebesar 7,7 dengan selisih rata-rata pengetahuan anak 0,08 .

Menurut (Septiana, 2018) menunjukan ada pengaruh edukasi media visual dengan metode kartu bergambar sebelum dan sesudah diberikan intervensi terhadap pengetahuan dan sikap anak dalam pemilihan jajanan sehat. Sedangkan menurut (Syofia, 2014) menyatakan tingkat pengetahuan responden sesudah diberikan penyuluhan meningkat menjadi kategori sedang dengan menggunakan flashcard, dan menurut (Maslakah, 2017) menunjukkan ada perbedaan yang signifikan pada variabel pengetahuan sebelum dan sesudah penyuluhan dengan menggunakan flash card.

Selain itu, penelitian ini juga sejalan dengan hasil penelitian (Demitri., 2015) terbukti bahwa game puzzle dapat meningkatkan pengetahuan anak sekolah yaitu pengetahuan anak sebelum dilakukan pendidikan gizi melalui game puzzle pada anak, kategori pengetahuan kurang baik sebesar 26,7\%, setelah dilakukan pendidikan gizi tidak ada lagi anak dalam kategori pengetahuan kurang baik.

Menurut (Oldewage-Theron, 2009) hasil penelitian menunjukkan bahwa voedingskennis van die respondente swak was, maar die kennis het sta- tisties betekenisvol $(p \leq 0,05)$ verbeter met $67 \%$ van die vrae wat voedingskennis getoets het na die im- plementering van die intervensie. Die kennis van voedselgroepe het verbeter van $13,4 \%$ voor tot $64,8 \%$ na die intervensie. Die funksies van die verskillende voedselgroepe met korrekte antwoorde het verbeter van 13,5-27,4\% voor tot $60,2-77,9 \%$ na die intervensie.

Sedangkan menurut hasil penelitian (Hikmawati, 2016) terbukti bahwa media puzzle berpengaruh dalam meningkatkan pengetahuan responden yaitu pengetahuan esponden sebelum diberikan penyuluhan dengan media puzzle terdapat 44,2\% responden dengan kategori cukup dan 55,8\% dengan kategori kurang dan meningkat setelah diberikan penyuluhan dengan media puzzle sebesar $88,4 \%$ dengan kategori cukup, 11,6\% dengan kategori kurang.

Selain itu menurut (Nita Prameswari, 2018) dari 53 siswa (98,1\%) dengan permainan puzzle dan bernyanyi menunjukkan sikap yang positif terhadap gemar makan ikan. Hal ini menunjukkan adanya peningkatan jumlah siswa yang menyatakan sikap gemar makan ikan jika dibandingkan dengan pretest (sebelum diberikan intervensi promosi gemar makan ikan), yaitu 92,6\%. 


\begin{tabular}{|l|l|r|}
\hline & Al Fitrah & Pengaruh Edukasi Gizi Seimbang \\
Journal Of Early Childhood Islamic Education & dan Puzzle... \\
ISSN : 2599-2287 E-ISSN : 2622-335X & Affifah Nufaisah, Emy \\
& Vol.3 No.1Juli 2019 & Yuliantini, Darwis \\
\hline
\end{tabular}

\section{Kesimpulan}

Simpulan dari penelitian ini : 1) Pengetahuan anak sebelum diberikan edukasi gizi seimbang dengan permainan kartu bergambar rata-rata skor yaitu 45.62. 2) Pengetahuan anak sebelum diberikan edukasi gizi seimbang dengan permainan puzzle rata-rata skor yaitu 43.88. 3) Pengetahuan anak sesudah diberikan edukasi gizi seimbang dengan permainan kartu bergambar rata-rata skor yaitu 80.46. 4) Pengetahuan anak sesudah diberikan edukasi gizi seimbang dengan permainan puzzle rata-rata yaitu 72.96. 5) Permainan yang lebih berpengaruh adalah permainan kartu bergambar yang dilihat dari hasil ratarata selisih pengetahuan sebelum dan sesudah diberikan edukasi menggunakan permainan kartu bergambar yaitu rata-rata skor $34.84 \quad$ sedangkan edukasi menggunakan permainan puzzle lebih rendah yaitu rata-rata skor 29.08 .

\section{Saran}

Saran pada penelitian ini : 1) Bagi peneliti selanjutnya bisa menggunakan metode edukasi yang lain (seperti food model atau piring makanku) dan mengetahui lebih banyak lagi seperti sikap dan tindakan dari anak tentang 10 pesan gizi seimbang dan dapat juga menggunakan media yang lain seperti video agar informasi yang akan disampaikan dapat diterima dengan mudah. 2) Bagi anak untuk dapat mengaplikasikan dalam kehidupan sehari-hari dari pengetahuan yang sudah didapat mengenai 10 pesan gizi seimbang. 3) Bagi institusi terkait, meningkatkan pengetahuan anak yang masih belum mengetahui 10 pesan gizi seimbang dengan melakukan permainan kartu bergambar dan puzzle, serta mensosialisasikan kembali bagaimana cara permainan puzzle dan kartu bergambar sebagai media untuk pembelajaran.

\section{Daftar Pustaka}

Achadi, Endang, Pujonarti, Siti A, Sudiarti, Tini, Rahmawati, Kusharisupeni, Mardatillah, K. Y. Putra, Wahyu. 2010. Sekolah Dasar Pintu Masuk Perbaikan Pengetahuan, Sikap, dan Perilaku Gizi Seimbang Masyarakat. Jurnal Kesehatan Masyarakat Nasional, 5, (1) : 43. Arikunto S. 1997. DasarDasar Evaluasi Pendidikan. Bumi Aksara. Jakarta

Arikunto S. 2006. Prosedur Penelitian Suatu Pendekatan Praktik. Edisi Revisi VI. Penerbit PT Rineka Cipta. Jakarta.

Arsyad, Azhar. (2013). Media Pembelajaran. Jakarta: PT. Raja Grafindo Persada.

Azwar S, 2003. Sikap manusia, Teori dan Pengukurannya. Pustaka Pelajar. Yogyakarta.

Bulan Febry, Ayu. 2013. Ilmu Gizi Untuk Praktisi Kesehatan. Graha Ilmu. Yogyakarta.

Demitri, Athira. 2015. Pengaruh Pendidikan GiziI tentang Pola Makan Seimbang Melalui Game Puzzle dan Gambar AnimasiI Terhadap Peningkatan Pengetahuan Anak SDN 067690 Kota Medan. Fakultas Kesehatan Masyarakat Universitas Sumatera Utara. Medan.

Djaali, Muljono, P., dan Ramly. 2000. Pengukuran dalam Bidang Pendidikan. PPS UNJ. Jakarta.

Hikmawati, Zainab, Yasnani, Sya’ban, Abdul Rahim. 2016. Pengaruh Penyuluhan dengan Media Promosi Puzzle Gizi terhadap Perilaku Gizi Seimbang Pada Siswa Kelas V di SD Negeri 06 POASIA Kota Kendari Tahun. Jurnal Fakultas Kesehatan 


\begin{tabular}{|l|l|}
\hline & A1 Fitrah \\
Journal Of Early Childhood Islamic Education \\
ISSN : 2599-2287 E-ISSN : 2622-335X \\
Vol.3 No.1Juli 2019
\end{tabular}

Pengaruh Edukasi Gizi Seimbang dengan Permainan Kartu Bergambar

Afifah Nufaisah, Emy Yuliantini, Darwis

Masyarakat Universitas Halu Oleo : 1-4.

Kementrian Keseharan RI. 2014. Pedoman Gizi Seimbang. Kementrian Keseharan RI. Jakarta.

Maslakah, Nisaul, Setiyaningrum, Zulia. 2017. Pengaruh Pendidikan Media Flashcard Terhadap Pengetahuan Anak Tentang Pedoman Umum Gizi Seimbang Di Sd Muhammadiyah 21 Baluwarti Surakarta. Jurnal kesehatan, 10 (1) : 13

Nita Prameswari, Gita. 2018. Promosi Gizi Terhadap Sikap Gemar Makan Ikan Pada Anak Usia Sekolah. Universitas Negeri Semarang : 4

Notoatmodjo, Soekidjo. 2003. Pendidikan Dan Perilaku Kesehatan. Rineka Cipta. Jakarta.

Notoatmodjo, S. 2007. Promosi Kesehatan dan Ilmu Perilaku. Rineka Cipta. Jakarta.

Purwoastuti, Th. Endang, Walyani. 2015. Prilaku dan Soft skills Kesehatan. Pustakabarupress. Yogyakarta.

Oldewage-Theron, W ILNA H, AA Egal. The Evaluation of $A$ Nutrition Education Programme On The Nutrition Knowledge of Children Aged Six And Seven Years. Journal of Family Ecology and Consumer Sciences, 37: 1.

Sadiman, Arif Sukadi, Sudjarwo, Radikun. 1989. Beberapa Aspek Pengembangan Sumber Belajar. PT. MEDIYATAMA SARJANA PRAKARSA. Jakarta.

Septiana, Pina, Suaebah. 2018. Edukasi Media Kartu Bergambar Berpengaruh Terhadap Pengetahuan Dan Sikap Anak Dalam Pemilihan Jajanan Sehat Di Sd Negeri Pontianak Utara. Pontianak Nutrition Journal (PNJ), 1, (02) : 1.

Soebachman, Agustina. 2012. Pemainan Asyik Bikin Anak Pintar. IN AzNa Books. Yogyakarta.
Soekanto, Soerjono. 2002. Sosiologi Suatu Pengantar. Raja Grafmdo Persada. Jakarta.

Sugiyono. 2013. Metode Penelitian Pendidikan Pendekatan Kuantitatif, Kualitatif, dan R\&D. Alfabeta. Bandung.

Sunarti, Euis dan Rulli Purwanti. 2005. Ajarkan Anak Keterampilan Hidup Sejak Dini. Alex Media Komputindo, Jakarta.

Surya, Mohammad. 2015. Strategi Kognitif dalam Proses Pembelajaran. Alfabeta. Bandung.

Susilowati, Kuspriyanto. 2016. Gizi Dalam Daur Kehidupan. PT. Refika Aditama. Bandung.

Supriasa, I Dewa Nyoman. 2015. Pendidikan \& Konsultasi Gizi. EGC. Jakarta.

Syofia, Siagian, Albiner, Nasution, Ernawati. 2014. Pengaruh Penyuluhan Makanan Bergizi Beragam Seimbang Dan Aman Dengan Menggunakan Flash Card Dalam Meningkatkan Pengetahuan Dan Sikap Anak Kelas 1 - 3 Sd Islam Titi Berdikari Kecamatan Medan Labuhan Tahun 2014. Program Sarjana Fakultas Kesehatan Masyarakat Universitas Sumatera Utara : 3.

Undang-Undang Republik Indonesia Nomor 20 Tahun 2003. Sistem Pendidikan *Nasional. 8 juli 2003. Lembaran Negara Republik Indonesia Tahun 2003 Nomor 4301. Jakarta.

Virmando, Eri, Anantanyu, Sapja, Kusnandar. 2018. Pengaruh Teknik Bernyanyi dan Permainan Kartu Bergambar terhadap Sikap dan Perilaku Gizi pada Anak Taman Kanak-Kanak. Jurnal MKMI, 14 (2) : 151.

Wawan dan Dewi M. 2010. Teori \& Pengukuiran Pengetahuan, Sikap, dan Perilaku Manusia. Nuha Medika. Yogyakarta 


\begin{tabular}{|l|l|r||}
\hline & Al Fitrah & Pengaruh Edukasi Gizi Seimbang \\
Journal Of Early Childhood Islamic Education & dengan Permainan Kartu Bergambar \\
ISSN : 2599-2287 E-ISSN : 2622-335X & Afifah Nufaisah, Emy \\
\hline & Yuliantini, Darwis \\
\hline
\end{tabular}

Wahyuningsih, Ni Putu, Nadhiro, Siti Rahayu, Adriani, Merryana. 2015. Media Pendidikan Gizi Nutrition Card Berpengaruh Terhadap Perubahan Pengetahuan Makanan Jajanan Anak Sekolah Dasar. Media Gizi Indonesia, 10 (1) : 26-27.

Yulianti I, Rani. 2008. Permainan yang Meningkatkan Kecerdasan

Anak.Laskar Askara. Jakarta. 